\title{
Dynamics of degradation of new samples of membrane coating based on cellulose polymers
}

\author{
Viacheslav Alexandrovich Lipatov ${ }^{1}$, Mikhael Alexandrovich Inarkhov, \\ Dmitriy Mutalifovich Yarmamedov ${ }^{1}$, Anna Jurievna Poddelkova ${ }^{1}$, Samuel Bisilki Governor ${ }^{2}$, \\ Prince Twumasi Ankrah ${ }^{3}$
}

\author{
${ }^{1}$ Department of Operative Surgery and Topographic Anatomy, Kursk State Medical University, Russia \\ ${ }^{2}$ Yaroslav-the-Wise Novgorod State University \\ ${ }^{3}$ Dagestan state medical academy
}

Received: 19 September 2015

Revised: 02 October 2015

Accepted: 10 October 2015

\section{*Correspondence:}

Prince Twumasi Ankrah,

E-mail: twumasiprince7@gmail.com

Copyright: (C) the author(s), publisher and licensee Medip Academy. This is an open-access article distributed under the terms of the Creative Commons Attribution Non-Commercial License, which permits unrestricted non-commercial use, distribution, and reproduction in any medium, provided the original work is properly cited.

\begin{abstract}
Background: The use of polymeric coating implants is a promising way of preventing adhesion disease and its related complications in the peritoneum. In this paper, the dynamics of degradation of new samples were studied in an in vitro experiment. A sample was then chosen which is potentially suitable for further research in an in vivo experiment.

Methods: In the research, 7 different samples of polymeric coating were studied viz. No. 81 MN, No 82. MN, No. 83 MN, No. 84 MN, No. 85 MN, No. 86 MN and No. 87 MN - developed by Lintex, LCC (St. Petersburg) together with the department of Operative Surgery and Topographical Anatomy named after A.D. Myasnekov of Kursk State Medical University. The samples were differentiated by subjecting them to different technological processing of temperature, and chemical agents etc.

Results: In the course of the experiment, it was discovered that the rate of degradation of the polymeric coating implants depended on their processing methods.

Conclusions: Membranes that quickly undergo degradation cannot be used for prophylaxis of complications caused by surgical interventions.
\end{abstract}

Keywords: Degradation; Polymer; Implantology; Membrane; Film; Adhesion formations

\section{INTRODUCTION}

Postoperative adhesive disease (PAD) is a globally widespread condition. This problem first arose when surgeons began operating on abdominal organs, yet there has been no effective solution to it till date. PAD reduces the quality of life of many patients and leads to acute adhesive intestinal obstruction (AIO). The occurrence of relapse of the condition is $60-70 \%$; acute $\mathrm{AIO}$ is the most common form of intestinal obstruction. ${ }^{1-3}$
Annual discussions among specialists about this problem in conferences and congresses, constant publications in periodic scientific literature with suggestions on prophylaxis and treatment of abdominal adhesion tell about constant interest in this problem.

We consider that the use of agents, which possess a barrier action, is the most optimal and pathogenetically substantiated way of preventing peritoneal adhesions. The use of a temporal barrier of polymeric resorbable implants gives us the most prospect of preventing peritoneal adhesions. The presence of a barrier agent, 
placed in an area, where surgical operation has been done provides not only the optimal conditions for regeneration of the injured tissues and organs of the abdominal cavity but also, with the aid of hydroflotation, creates an interposition between the injured or inflamed peritoneal surfaces.

The use of polymeric barrier agents, particularly, in the form of membranes, helps to achieve a sufficient long and effective action.

Suggested prophylactic solutions to Postoperative Adhesive Disease- polytetrafluoroethylene (Preclude and Gore-Tex Surgical Membrane, W.L Gore Corp) - an insoluble membrane produced from thin sheets $(0.1 \mathrm{~mm})$ of stretched polytetrafluoroethylene with pores averaging less than $2 \mu \mathrm{m}$, which is, non- adhesive and requires fixation to tissues with the help of sutures or staples and removal at a later period.

Sodium hyaluronic acid- a transparent and absorbable coating, which within a period of 7 days, separates organs and tissues nearby but easily breaks down when manipulated. ${ }^{4}$ Unfortunately, an effective choice of treatment and prophylaxis of PAD does not exist. ${ }^{5-8}$

The use of polymeric coating implants (PCI), which creates a temporal barrier between injured tissues, gives hope in attaining a significant clinical anti-adhesion effect. ${ }^{9,10}$

The duration of dissolution of the polymeric coating implant is key to the separation of injured surfaces, and the prevention of scars and adhesions; thus, polymeric coating implant with a sufficient duration of dissolution, will achieve a clinical anti-adhesion effect.

Considering the results of our previous experiments as well as the results of the scientific findings of our colleagues published in literature sources, together with Lintex, LLC we produced a series of membranes with the aim of increasing the duration of degradation, and consequently, increasing the anti-adhesion effect.

The aim of this research is to study the dynamics of degradation of new samples of polymeric coating implants in an in vitro experiment and to conclude which samples have the best parameters.

\section{METHODS}

In the research, 7 different samples of polymeric coating were studied viz. No. $81 \mathrm{MN}$, No 82. MN, No. $83 \mathrm{MN}$, No. $84 \mathrm{MN}$, No. $85 \mathrm{MN}$, No. $86 \mathrm{MN}$ and No. $87 \mathrm{MN}$ developed by Lintex, LCC (St. Petersburg) together with the department of Operative Surgery and Topographical Anatomy named after A.D. Myasnecov of Kursk State Medical University. The samples were differentiated by subjecting them to different technological processing of temperature, and chemical agents etc.
For comparative analyses, 60 equal parts with a size of $2 \times 1 \mathrm{~cm}$ from each of the 7 samples of polymeric coating implants were used. These were placed in 420 test tubes, each containing $25 \mathrm{ml}$ of $0.9 \% \mathrm{NaCl}$ solution, which corresponds to the normal average amount of free fluid in the peritoneum. The test tubes were kept in a thermostat at a constant temperature of $37^{\circ} \mathrm{C}$.

In the course of the experiment, the implants were removed from the thermostat in correspondence with the established time criteria ( 1 hour, 1 day, 3 days, 7 days, 14 days, 21 days, 30 days and 60 days), and changes in their form and state were observed. After the removal of the coating membranes from the test tubes, the degree of degradation of the coating membranes was evaluated; and the thickness and mass measured; and the volume and density of the samples calculated using formulas. By a score scale developed by the authors, the degree of degradation of the implants was evaluated, taking into consideration the most significant changes (softening, thickening, fragmentation, physical state). ${ }^{11}$ The scale for the scoring of the dynamic changes of the qualitative parameters of PCI is presented in Table 1.

A statistical processing was carried out with the help of a program (Biostat). For comparison, Mann-Whitney U test was used; the critical value of significance (p) was 0.05 .

\section{RESULTS}

Table 2 was drawn based on the developed point scoring system for the changes in the qualitative characteristics of PCI.

From this, the properties of the membranes of samples 82 $\mathrm{MN}, 83 \mathrm{MN}, 84 \mathrm{MN}$ and $85 \mathrm{MN}$ remained stable throughout the experiment; softening was not observed. Elasticity and flexibility of the membranes were the same as the initial sample. Softening was observed in coatings $81 \mathrm{MN}$ and $86 \mathrm{MN}$ from the $30^{\text {th }}$ day and $14^{\text {th }}$ day respectively during the experiment. For PCI $87 \mathrm{MN}$, softening was noticed on the $14^{\text {th }}$ day; and on the $30^{\text {th }}$ day of the experiment, it had dissolved completely.

In the course of the experiment, thickening of the membrane in all the samples was observed which caused difficulty in identifying the most optimum sample. In spite of that, during the experiment a decrease in the thickness of PCI $87 \mathrm{MN}$ was discovered, and on the $30^{\text {th }}$ day it dissolved completely.

The physical states of samples PCI $82 \mathrm{MN}, 83 \mathrm{MN}, 84$ $\mathrm{MN}, 85 \mathrm{MN}$ were constant (in their solid state) throughout the experiment. From day 30, samples $81 \mathrm{MN}$ and $86 \mathrm{MN}$ underwent softening and acquired a gelatinous consistency. Sample $87 \mathrm{MN}$ completely dissolved in an isotonic solution on day 30 .

During the experiment, fragmentation remained a stable parameter for all the PCI samples. For $82 \mathrm{MN}, 83 \mathrm{MN}$, 
$84 \mathrm{MN}$, and $85 \mathrm{MN}$, fragmentation was absent. Marginal destruction of not more than $30 \%$ of the area of the membrane was observed in $81 \mathrm{MN}$ and $86 \mathrm{MN}$ from days
60 and 30 respectively. Complete degradation was observed in $87 \mathrm{MN}$ on day 30.

Table 1: Point scoring system for the changes in the qualitative characteristics of PCI.

\begin{tabular}{|c|c|c|c|}
\hline $\begin{array}{l}\text { Qualitative } \\
\text { characteristics }\end{array}$ & Points and their characteristics & & \\
\hline $\begin{array}{l}\text { Softening } \\
\text { (S) }\end{array}$ & $\begin{array}{l}0 \text { point } \\
\text { (the elasticity and the flexibility } \\
\text { reduced more than twice) }\end{array}$ & $\begin{array}{l}1 \text { point } \\
\text { (the elasticity and flexibility was } \\
\text { not reduced more than twice) }\end{array}$ & $\begin{array}{l}2 \text { points } \\
\text { (the elasticity and flexibility } \\
\text { of the membrane remained } \\
\text { intact) }\end{array}$ \\
\hline $\begin{array}{l}\text { Thickening } \\
\text { (T) }\end{array}$ & $\begin{array}{l}0 \text { point } \\
\text { (the thickness of the membrane } \\
\text { reduced) }\end{array}$ & $\begin{array}{l}1 \text { point } \\
\text { (the thickness of the membrane } \\
\text { increased) }\end{array}$ & $\begin{array}{l}2 \text { points } \\
\text { (the thickness of the } \\
\text { membrane remained } \\
\text { unchanged) }\end{array}$ \\
\hline $\begin{array}{l}\text { Fragmentation } \\
\text { (F) }\end{array}$ & $\begin{array}{l}0 \text { point } \\
\text { (destruction of the membrane by } \\
\text { more than } 30 \% \text { of the area of the } \\
\text { membrane) }\end{array}$ & $\begin{array}{l}1 \text { point } \\
\text { (destruction of the edges of the } \\
\text { membrane was not more than } \\
30 \% \text { of its area) }\end{array}$ & $\begin{array}{l}2 \text { points } \\
\text { (absence of fragmentation) }\end{array}$ \\
\hline $\begin{array}{l}\text { Physical state } \\
\text { (P) }\end{array}$ & $\begin{array}{l}0 \text { point } \\
\text { (the membrane is in a liquid state) }\end{array}$ & $\begin{array}{l}1 \text { point } \\
\text { (the membrane is in a gelatinous } \\
\text { state) }\end{array}$ & $\begin{array}{l}2 \text { points } \\
\text { (the membrane is in a solid } \\
\text { state) }\end{array}$ \\
\hline
\end{tabular}

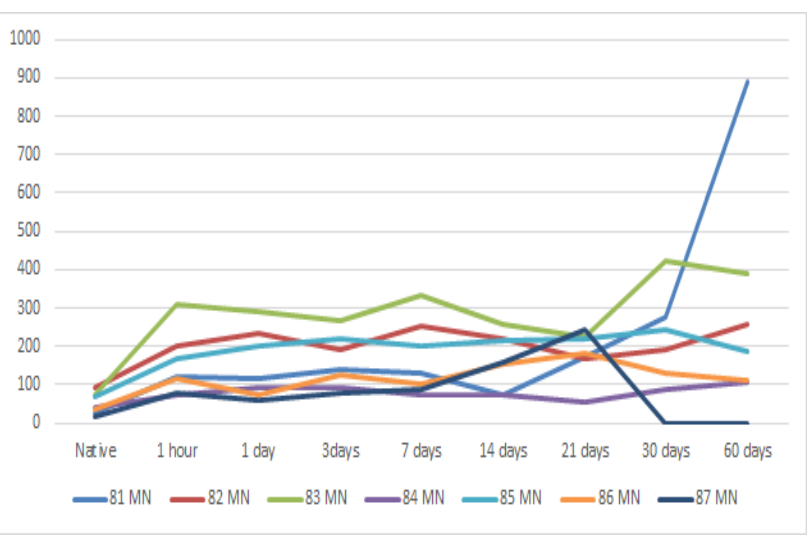

Figure 1: Change in mass of the samples (mg).

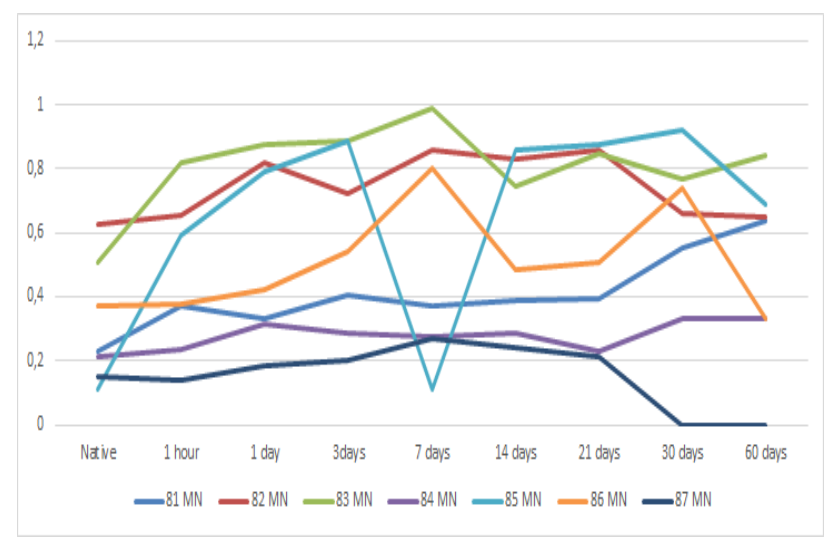

Figure 2: Change in thickness of the samples (mm).

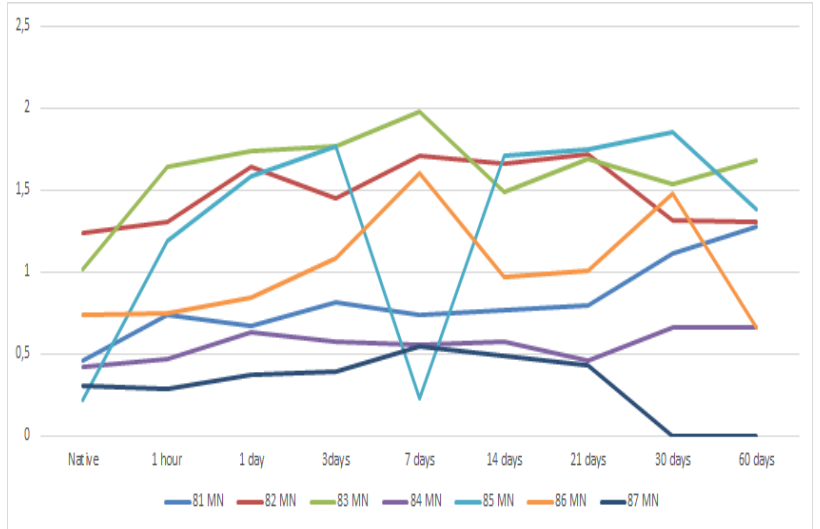

Figure 3: Changes in volume of the samples $\left(\mathrm{mm}^{3}\right)$.

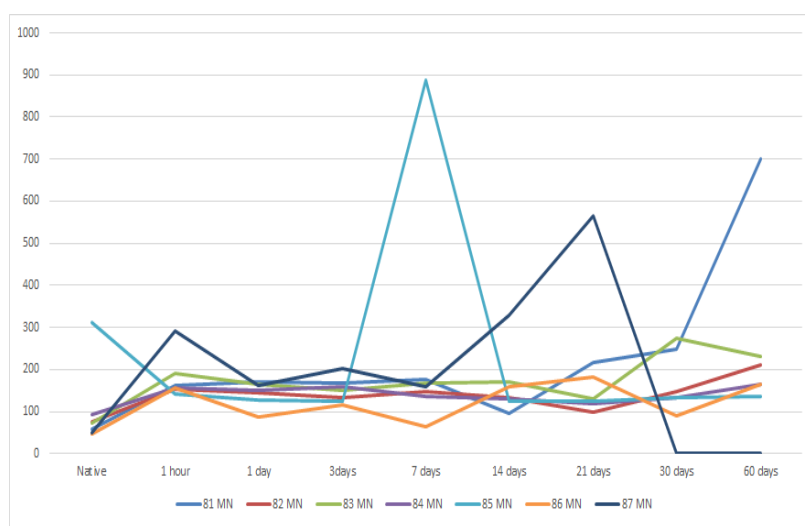

Figure 4: Changes in density of the samples (mg\mm). 
The results of the research showed that all the samples possess pronounced hydrophilic properties. The mass of the studied implants remained relatively stable till the $21^{\text {st }}$ day of the experiment. The mass of the coating of $83 \mathrm{MN}$ was more in comparison to other samples. On the $30^{\text {th }}$ day, after PCI $81 \mathrm{MN}$ was placed in an isotonic solution, the sample unevenly increased in mass. The mass of 87
MN reduced significantly on the $21^{\text {st }}$ day; and on the $30^{\text {th }}$ day, it underwent degradation. On the $60^{\text {th }}$ day of the experiment, it was impossible to distinguish samples 81 $\mathrm{MN}, 82 \mathrm{MN}, 83 \mathrm{MN}, 84 \mathrm{MN}, 85 \mathrm{MN}$ and $86 \mathrm{MN}$ from each other, as per the results of the experiment, they turned out to be identical.

Table 2: Point scoring system for the changes in the qualitative characteristics of PCI.

\begin{tabular}{|c|c|c|c|c|c|c|c|c|c|}
\hline Samples & Parameter & 1 hour & 1 day & 3 days & 7 days & 14 days & 21 days & 30 days & 60 days \\
\hline \multirow[t]{4}{*}{$81 \mathrm{MN}$} & Softening & 2 & 2 & 2 & 2 & 2 & 2 & 1 & 0 \\
\hline & Thickening & 1 & 0 & 1 & 0 & 1 & 1 & 1 & 1 \\
\hline & Fragmentation & 2 & 2 & 2 & 2 & 2 & 2 & 2 & 1 \\
\hline & Physical state & 2 & 2 & 2 & 2 & 2 & 2 & 2 & 1 \\
\hline \multirow[t]{4}{*}{$82 \mathrm{MN}$} & Softening & 2 & 2 & 2 & 2 & 2 & 2 & 2 & 2 \\
\hline & Thickening & 1 & 1 & 0 & 1 & 0 & 2 & 0 & 0 \\
\hline & Fragmentation & 2 & 2 & 2 & 2 & 2 & 2 & 2 & 2 \\
\hline & Physical state & 2 & 2 & 2 & 2 & 2 & 2 & 2 & 2 \\
\hline \multirow[t]{4}{*}{$83 \mathrm{MN}$} & Softening & 2 & 2 & 2 & 2 & 2 & 2 & 2 & 2 \\
\hline & Thickening & 1 & 1 & 1 & 1 & 0 & 1 & 0 & 1 \\
\hline & Fragmentation & 2 & 2 & 2 & 2 & 2 & 2 & 2 & 2 \\
\hline & Physical state & 2 & 2 & 2 & 2 & 2 & 2 & 2 & 2 \\
\hline \multirow[t]{4}{*}{$84 \mathrm{MN}$} & Softening & 2 & 2 & 2 & 2 & 2 & 2 & 2 & 2 \\
\hline & Thickening & 1 & 1 & 0 & 0 & 1 & 0 & 1 & 2 \\
\hline & Fragmentation & 2 & 2 & 2 & 2 & 2 & 2 & 2 & 2 \\
\hline & Physical state & 2 & 2 & 2 & 2 & 2 & 2 & 2 & 2 \\
\hline \multirow[t]{4}{*}{$85 \mathrm{MN}$} & Softening & 2 & 2 & 2 & 2 & 2 & 2 & 2 & 2 \\
\hline & Thickening & 1 & 1 & 1 & 0 & 1 & 1 & 1 & 0 \\
\hline & Fragmentation & 2 & 2 & 2 & 2 & 2 & 2 & 2 & 2 \\
\hline & Physical state & 2 & 2 & 2 & 2 & 2 & 2 & 2 & 2 \\
\hline \multirow[t]{4}{*}{$86 \mathrm{MN}$} & Softening & 2 & 2 & 2 & 2 & 1 & 1 & 0 & 0 \\
\hline & Thickening & 1 & 1 & 1 & 1 & 0 & 1 & 1 & 0 \\
\hline & Fragmentation & 2 & 2 & 2 & 2 & 2 & 2 & 0 & 0 \\
\hline & Physical state & 2 & 2 & 2 & 2 & 2 & 2 & 1 & 1 \\
\hline \multirow[t]{4}{*}{$87 \mathrm{MN}$} & Softening & 2 & 2 & 2 & 2 & 1 & 1 & 0 & 0 \\
\hline & Thickening & 0 & 1 & 1 & 1 & 0 & 0 & 0 & 0 \\
\hline & Fragmentation & 2 & 2 & 2 & 2 & 2 & 2 & 0 & 0 \\
\hline & Physical state & 2 & 2 & 2 & 2 & 2 & 2 & 0 & 0 \\
\hline
\end{tabular}

\section{DISCUSSION}

During the experiment, the values of the thickness of the polymeric implants constantly changed. On the $7^{\text {th }}$ day, a significant decrease in thickness was observed in $85 \mathrm{MN}$, after it was placed in an isotonic solution. The values of samples $81 \mathrm{MN}, 82 \mathrm{MN}$ and $83 \mathrm{MN}$ were high during the whole research. In the course of the experiment, it was discovered on day 60 that the membranes of $84 \mathrm{MN}$ and $86 \mathrm{MN}$ had undergone a reduction in thickness. Sample $87 \mathrm{MN}$ had undergone complete degradation.

During the experiment, it was discovered that the density of the given samples remained relatively stable.
Significant increase in density was observed in membranes $85 \mathrm{MN}$ and $87 \mathrm{MN}$ on days 7 and 21 respectively. On day 60 , PCI $81 \mathrm{MN}$ possessed the greatest density and $87 \mathrm{MN}$ underwent complete degradation. The rest of the membranes: $82 \mathrm{MN}, 83 \mathrm{MN}$, $84 \mathrm{MN}$ and $86 \mathrm{MN}$ had similar values. That is why distinguishing them from each other per the given values was impossible.

In the results of the research, a significant decrease in volume in implant $85 \mathrm{MN}$ was observed on day 7 whereas an increase in $86 \mathrm{MN}$ and $83 \mathrm{MN}$ was observed. On day 60 , the greatest values were of membranes- 81 $\mathrm{MN}, 82 \mathrm{MN}, 83 \mathrm{MN}$, and $85 \mathrm{MN}$ and the least, of 
membranes- $84 \mathrm{MN}$ and $86 \mathrm{MN}$. PCI $87 \mathrm{MN}$ completely dissolved in an isotonic solution of Sodium Chloride.

In the course of the experiment, it was discovered that the rate of degradation of the polymeric coating implants depended on their processing methods. Membranes that quickly undergo degradation cannot be used for prophylaxis of complications caused by surgical interventions. This is because their quick elimination from the abdominal cavity would not allow a sufficient continuous action for achieving a clinical effect.

Slowly degrading coatings on the contrary have prospects for further use. That is why subsequent research must be directly aimed at studying them. Sample $87 \mathrm{MN}$ underwent degradation on the $30^{\text {th }}$ day, which is an ample time, for the attainment of a clinical effect for prophylaxis against the formation of adhesions.

Also, in the future, it would be necessary to carry out the research in an in vivo experiment to ascertain the duration of dissolution of the coatings in an animal organism; since peristalsis of the intestines, peritoneal fluid and cells of the macrophage system will facilitate degradations; and will also lead to a change in the duration of reabsorption.

\section{CONCLUSION}

1. It was deduced from the result of the comparative analysis that the physical and manipulative property of the coating membrane, depend on the method (temperature, chemical agents, etc.) and the length of the processing.

2. In relating to the results of the conducted research; from the standpoint of time for degradation, it was concluded that sample MN 87 was the most suitable for an in vivo experiment. This is because the sample dissolved on the 30th day; thus, the time for regenerative process coincides with the time of biodegradation of membranes in an organism.

3. There needs to be a further research in an in vitro experiment, to determine the duration of degradation for the polymeric coating implants of: $81 \mathrm{MN}, 82$ $\mathrm{MN}, 83 \mathrm{MN}, 84 \mathrm{MN}, 85 \mathrm{MN}$, and $86 \mathrm{MN}$.

\section{ACKNOWLEDGEMENTS}

The authors are grateful to Lintex, LCC (St. Petersburg), a scientific subunit that manufactured the experimental samples, for their cooperation in carrying out the experiment.

Funding: No funding sources Conflict of interest: None declared

Ethical approval: The study was approved by the institutional ethics committee

\section{REFERENCES}

1. Boyko VV, Yevtushenko DA. Method of prophylaxis of adhesion-formation, on the organs of the peritoneum, of an early- operated- on- patients. Scientific innovation. 2013;25:177-81.

2. Adhesion disease of the Peritoneum. Plechev VV, Kiriyenko AI, Savelyev VC. 80 Lectures in surgery. 1st ed. Moscow, Moskva. 2008:456-68.

3. Khasanov AG, Sufiyarov IF, Nigmatzyanov SS, Matigullin RM. Method of surgical treatment and prophylaxis of post-operative peritoneal adhesion. Surgery Journal named Pirogov. 2008;3:43-5.

4. Fertil S. The Practice Committee of the American Society for Reproductive Medicine in collaboration with the Society of Reproductive Surgeons. Pathogenesis, consequences, and control of peritoneal adhesions in gynecologic surgery. 2008;90:144-9.

5. Ansaloni L, Catena F, Coccolini F, Fini M, Gazzotti F, Giardino R, et al. Peritoneal Adhesions to Prosthetic Materials: An Experimental Comparative Study of Treated and Untreated Polypropylene Meshes Placed in the Abdominal Cavity. Journal of Laparoendoscopic \& Advanced Surgical Techniques. 2009;19:369-74.

6. Costa RG, Lontra MB, Scalco P, Cavazzola LT, Gurski RR. Polylactic acid film versus acellular porcine small intestinal submucosa mesh in peritoneal adhesion formation in rats. Acta Cir Bras. 2009;24:128-35.

7. Degenhardt $P$, Pelzer $M$, Fischer $B$, Kraft $S$, Sarioglu N, Mau H, et al. Reduction of Postoperative Adhesions by Perfluorocarbons. An Experimental Study in a Rat Model. Eur J Pediatr Surg. 2009;19:211-5.

8. Zeng Q, Yu Z, You J, Zhang Q. Efficacy and safety of Seprafilm for preventing postoperative abdominal adhesion: systematic review and meta-analysis. World J Surg. 2007;31:2125-31.

9. Chapter I. In: V. A. Kargin. Encyclopedia of polymers. 4th ed. Moscow: Soviet Encyclopedia. 2000:77.

10. Stillman MI. Polymers of Medico- biological applications. M. Academic- book. 2nd ed. Moscow, Moskva. 2006:400.

11. Lipatov VA, Inarhov MA, Zhukovsky VA, Yarmamedov DM, Tsupreva EA. Dynamics of degradation of polymeric coating implants in the conditions of an experiment in vitro.Youth Innovation Gazette. 2013;1:111-2.

12. Chen L, Hu A, Chang C. The Degradation Mechanism of Toxic Atractyloside in Herbal Medicines by Decoction. Molecules. 2013;18:201828.

13. Ishimoto T, Koyama M. A Review of MolecularLevel Mechanism of Membrane Degradation in the Polymer Electrolyte Fuel Cell. Membranes. 2012;2:395-414. 
14. Ji M, Wei Z. A Review of Water Management in Polymer Electrolyte Membrane Fuel Cells. Energies. 2009;2:1057-106.

15. Scipioni R, Gazzoli D, Teocoli F, Palumbo O, Paolone A, Ibris N, Brutti S. Preparation and Characterization of Nanocomposite Polymer
Membranes Containing Functionalized $\mathrm{SnO} 2$

Additives. Membranes. 2014;4:123-42.

Cite this article as: Lipatov VA, Inarkhov MA, Yarmamedov DM, Poddelkova AJ, Governor SB, Ankrah PT. A retrospective study of colorectal carcinoma in Central India. Int Surg J 2015;2:670-5. 